\title{
Protecting Children from Child Abuse \& Neglect in Egypt: Addressing Neighborhood Factors
}

\author{
Beverly C. Sealey, PhD, MSW, LICSW \\ Simmons College School OF Social Work, \\ Boston, MA (USA)
}




\section{Egyptian Journal of Social Work (EJSW) http://ejsw.journals.ekb.eg \\ Print ISSN: 2356-9204 Online ISSN: 2356-9212 Vol 1, Issue 1, June 2015}

\section{Abstract:}

This paper was an invited presentation on child abuse and neglect, at the Twenty-second International Conference of Social Work, at Helwan University, Cairo Egypt, on March 9 \& 10, 2009. The purpose of this presentation was to increase understanding among social work professionals and students of the prevalence and consequences of child maltreatment such as child abuse, child neglect, and child exploitation of children under the age of 18 years by their parents and caretakers.

This article discusses the definition of what constitutes child abuse and child neglect; what are the various forms of child abuse and child neglect; the causes and consequences of child abuse and neglect; global issues of abuse of children (Roth, W. 2011) and, how to identify the signs of child abuse and neglect. This paper offers a model for preventing child abuse and neglect, to help children survive, and strengthen families through neighborhood factors.

Key Words: Global Child Abuse, Neighborhood Factors, Prevention of Child Abuse.

\section{Introduction}

According to a report published by UNICEF, the Situation of Women and Children in Egypt (Retrieved 11/16/2008, from http://ww.unicef.org/egypt/overview.html), a 2006 study on child abuse in deprived urban communities [in Egypt] shows $81 \%$ of children having been corporally punished at home in the preceding year, and $91 \%$ corporally punished during the same period in schools.

Youssef and Atta (1998), in their study of the perception of child abuse and neglect by professionals who work with children in Egypt, found that there is a scarcity of knowledge about child maltreatment in Arab countries. The authors found in their study of physicians, teachers, and social workers in Egypt, that children are subjected to physical abuse, but this may be in a "disciplinary context." The authors further commented that the recognition of maltreated children relies in part on the willingness of professionals to accept that the condition exists. Professionals may acknowledge that child physical abuse may occur, but deny that there exist other forms of child maltreatment and neglect. 
According to Bibars (1998) and others,

“" ... There is very little data on the number of street children in Egypt and on the severity of the problems they face. However, observing the large numbers of poor children on the streets of Cairo and other large Cities of Egypt (... begging, running errands, parking and/or cleaning cars, etc., and how these numbers have changed suggests that the problem is on the increase (p. 203)."

A report published by UNICEF states "there is a need to institutionalize child protection mechanisms and services for monitoring and rehabilitation of children subjected to exploitation, abuse, violence, and those deprived of primary care (UNICEF Egypt - Overview - The Situation of Children and Women in Egypt. Retrieved November 16, 2008, from http://www.unicef.org/egypt/overview.html). Another report by UNICEF states that there is a need for additional services to protect children from violence, abuse and neglect in Egypt. Retrieved November 16 , 2008

from

http://www.unicef.org/infobycountry/egypt.html.

Why do parents and/or caretakers abuse or neglect their children? Children are said to be "our prized possessions, our future, and to grow up in a family, a community, and a society where a child is either victimized by his or her parents or caretakers, who are discriminated against in society, or who are cast away as worthless objects, grow up to become burdens on the state and society.

According to Youssef and Atta (1998), "child maltreatment is more likely to exist in disrupted families, as well as those living under unfavorable circumstances, suffering from economic hardship or isolated from the community social network (p. 1)."

\section{Definition of Child Abuse \& Neglect}

There is no one definition or set of definitions for what constitutes child abuse and neglect, or child maltreatment. There are numerous definitions, and the culture of any given society may influence what constitutes abuse and neglect against children.

Perpetrators of child abuse and/or neglect are usually said to be those individuals who are either the child's parent(s) or caretaker(s). A 
caretaker is a child's parent, stepparent, guardian, any household member entrusted with the responsibility for a child's health or welfare, or any other person entrusted with the responsibility for a child's health or welfare whether in the child's home a relative's home, a school setting, a day care setting (including babysitting), a foster home, a group care facility, or another other comparable setting. "Caretaker" includes schoolteachers, babysitters, school bus driver's camp counselors, etc.

Child abuse includes physical abuse of a child under age 18, physical injury, Shaken Baby Syndrome, Child Sexual Abuse, Psychological or Emotional Abuse, Institutional Abuse.

\section{Overview of Child Abuse and Neglect}

Child abuse includes acts of physical abuse, physical injury, shaken baby syndrome, sexual abuse, emotional abuse and exploitation, emotional injury, and institutional abuse. On the other hand, Child Neglect includes the failure to provide for a child's basic human needs of food, shelter, clothing, supervision, opportunity to grow up healthy, emotional, educational, medical, psychological and social neglect, and failure to thrive.

\section{Abuse:}

According to the General Laws of the Commonwealth of Massachusetts, Massachusetts General Law, Chapter 51 (M.G.L, Chapter 51) abuse is the non-accidental commission of any act, by a parent or caretaker, upon a child under the age of 18, which causes or creates a substantial risk of physical or emotional injury, constitutes a sexual offense under the laws of the Commonwealth, or any sexual contact between a caretaker and a child under the care of that individual. Abuse is any action that creates an injury or a substantial risk of injury to a child. Abuse can be physical, sexual or emotional. Physical abuse includes beating, shaking, kicking, burning, or other types of bodily harm that can result in bruises, fractures, broken bones, internal injuries, or death.

\section{Physical Injury:}

Physical injury can be the result of physical abuse. Any physical injury that is not clearly explained may be a possible indicator of physical abuse. Physical injury may include death, 
fractures of bones, burns, impairment of any organ, and any other such nontrivial injury; soft tissue swelling or skin bruising; addiction to alcohol and/or drugs; or, failure to thrive.

\section{Shaken Baby Syndrome:}

Infants, babies, or small children who suffer injuries or death from severe shaking, jerking, pushing or pulling may have been victims of Shaken Baby Syndrome. The act of shaking a baby is considered physical abuse, as spinal head and neck injuries often result from violently shaking young children. It has been estimated that about 50 percent of children who are victims of Shaken Baby Syndrome die from their injuries.

\section{Child Sexual Abuse:}

Child sexual abuse occurs when an adult caretaker has any sexual contact with a child. This can happen through sexual intercourse, which is considered rape under state laws. It includes any oral, genital, or anal penetration. Sexual exploitation and molestation are also considered abuse. These are defined as contact or interaction with a child that is used to satisfy an adult's sexual needs and desires. This includes any verbally enticing language, as well as fondling, masturbating or exposure of sexual organs by the adult. Sex between adults and children is never considered consensual.

\section{Psychological Abuse:}

Psychological abuse is a chronic pattern of behaviors such as belittling, humiliating, and/or ridiculing the child.

\section{Child Neglect:}

Child neglect is a broader term, and one that is often misunderstood. Neglect is the failure by a parent or caretaker, either deliberately, through negligence, or inability to take those actions necessary to provide a child with minimally adequate food, clothing, shelter, medical care, educational opportunity, safety and protection, supervision, emotional stability and growth, or other essential care; provided. However, that such inability is not due solely to inadequate economic resources or solely to the existence of a caretaker's handicapping condition. A child can be considered neglected when a caretaker does not provide for basic needs, either deliberately or 
Egyptian Journal of Social Work (EJSW) http://ejsw.journals.ekb.eg

Print ISSN: 2356-9204 Online ISSN: 2356-9212 Vol 1, Issue 1, June 2015

through negligence. An infant born addicted to drugs is considered neglected as well.

\section{Psychological Neglect:}

Psychological neglect is the consistent failure of a parent or caretaker to provide a child with appropriate support, attention, and affection.

\section{Child Exploitation:}

Child exploitation takes the form of child sex trafficking, pornography, prostitution, or other uses of children under the age of 18 for sexual gratification; forced child labor; and, use of children as child soldiers.

\section{CAUSES OF CHILD ABUSE AND NEGLECT}

Why do parents and/or caretakers abuse or neglect children? Research on the causes of child abuse and neglect has documented many causes for child maltreatment: family poverty, divorce and/or separation of parents, unwed parenting, teenage and young mothers, and parental social and emotional or psycho-pathological problems. Parental substance abuse, parental stress, lack of support and isolation of parents, and physical or emotional handicaps in one's child or children demanding the time and attention of parents and/or caretakers. Lastly, domestic violence and substance abuse are also found to be strong predictors of child maltreatment (US DHHS Bulletin, Children and Domestic Violence, 2003). Some research also points out that racial, ethnic, linguistic, and poverty could also be causes for high incidents of child maltreatment.

\section{Consequences of Child Abuse and Neglect}

According to Youssef and Atta (1998), "the problem of child maltreatment is multidimensional and has legal, social, medical, and psychological ramifications" (p. 2). As a result of child maltreatment, infants and children may die, while others may develop long-term effects of maltreatment such as permanent mental or physical disability. Problems of maladjustment during childhood as well as adult life may be persistent. Children who have been or are victims of child abuse and neglect are often in trouble in school and may have either learning disabilities or conduct disorders. These children tend to be depressed, isolated, or alienated from mainstream, stigmatized, 
and aggressive, and exhibit social problems such as juvenile delinquency, running away from home and living on the street. Many child victims become perpetrators of crime, street children, and adults unable to be self-sufficient and care for themselves. To what extent a society can tolerate these problems in a society determines the quality of that society. Lastly, the children themselves may become perpetrators of abuse themselves as adults, and perpetuate the cycle of violence.

Research has documented that child maltreatment and exposure to violence in the home and community can have long-term negative psychological, emotional, physical, social, relational, and work consequences. Children who have experienced severe forms of abuse and/or neglect are not able to develop in a healthy and secure environment that will allow them to become stable, well-functioning members of society. Depending on the type of abuse or neglect experienced, children will have problems contributing to their community and society in ways that are healthy, and will promote the norms, values, and mores of any particular society.

Some of the effects of child abuse include problems with completing a formal education so that one could locate work as adults; developing and maintaining healthy and productive relations with members of the opposite sex in order to marry and raise a family satisfactorily. Some children may develop brain damage, learning difficulties, and other forms of handicaps. They may end up on the streets at an early age, and as street children and adults, they will live a life of harm, illness and disease.

According to the 1990 World Summit for Children (Unicef) “... Each day, countless children around the world are exposed to dangers that hamper their growth and development. They suffer immensely as casualties of war and violence; as victims of racial discrimination, apartheid, aggression, foreign occupation and annexation; as refugees and displaced children, forced to abandon their homes and their roots; as disabled; or as victims of [child abuse], neglect, cruelty, and exploitation." (Retrieved 11/22/08, from http://www.unicef.org/wsc/declare.htm. 
Egyptian Journal of Social Work (EJSW) http://ejsw.journals.ekb.eg

Print ISSN: 2356-9204 Online ISSN: 2356-9212 Vol 1, Issue 1, June 2015

\section{History of Child Abuse \& Neglect}

Child abuse and neglect is an age-old phenomenon. Children have been killed, beaten, maimed, and seduced throughout history, at the hands of their parents and caretakers. Worldwide, children have increasingly become victims of violence in the home and community. Many children are victims of child maltreatment, including child abuse, neglect and exploitation, and for whom many have been abandoned and relegated to living on the street. To maltreat children is a serious societal problem that has deleterious effects for not only the child, but also the family of the child, the community, and society.

Historically, children were regarded as chattel, or property of their parents. Parents had total control of their child's life and death. Early cultures that sexually misused children were acceptable in early Greece. For example, men using young boys sexually were practiced extensively. Early religions saw children offered as sacrifice. The circumstances of parents dictated the circumstances of their child or children. In the United States, poor parents were subject to almshouses, where they went with their children. Children who arrived to the United States as immigrants were required to work alongside their parents. Black children came originally as slaves who were at the mercy of the slave masters or the slave owner. It was not unusual for these children to be beaten or separated from their families according to the needs of their slave owners.

\section{Influence of Research on Battered Child Syndrome on Responses to Child Abuse and Neglect:}

\section{Battered Child Syndrome and the Best Interest of the Child}

\section{Movement:}

It was not until the 1950's that child abuse again became a concern, due largely to the efforts of Dr. C. Henry Kempe and other physicians. In 1962, Dr. Kempe, Department of Pediatrics of the Colorado School of Medicine, published an article that highlighted what he termed the "Battered Child Syndrome" (Crosson-Tower, 1992). Consequently, "child maltreatment emerged as a relatively new arena and a distinct area of expertise, [and] ... children who were subjected to all forms of abuse or neglect became regularly encountered, and ... child maltreatment became recognized as a social 


\section{Egyptian Journal of Social Work (EJSW) http://ejsw.journals.ekb.eg}

Print ISSN: 2356-9204 Online ISSN: 2356-9212 Vol 1, Issue 1, June 2015

problem in both developed and developing parts of the world" (Youssef, R. M. and Atta, H. Y. 1998, p. 1).

\section{Movements on the Rights of the Child:}

About the same time that we saw the Battered Child Syndrome and the Best Interest of the Child Movement, there were important treaties that were developed and ratified by the United Nations (the U. N. Declaration on the Rights of the Child (1959), The Organization of African Unity (OAU), and the African Charter on the Rights and Welfare of the Child). These treaties were developed, ratified, and implemented to protect the human rights of children all over the world, with respect to access to services to provide for the basic human needs.

\section{CHILD DEVELOPMENT AND BASIC HUMAN NEEDS}

Abraham Maslow (1943), a psychologist and researcher, found in his research that all people, regardless of culture, are motivated by basic human needs. According to Maslow, our most basic needs are inborn and instinctual. Maslow found that all humans [regardless of culture] start with a very weak position that is then fashioned fully as the person grows. If the environment is "right", people will grow up to be healthy and well-balanced adults, actualizing the potentials they have inherited. If the environment is not "right", they will not grow well. According to Maslow, human needs arrange themselves in "hierarchies of pre-potency." The appearance of one need usually rests on the prior successful fulfillment of the previous stage.

Maslow (1943) found in his research on human motivation that all human beings have a hierarchy of basic human needs. He found that these needs were hierarchical, that consisted of five stages:

The first stage characterizes the biological and physiological needs, or basic survival needs such as air, water, food, shelter, clothing, and warmth. If the basic needs of the first stage are not met, the individual will not be able to successfully advance to the second and subsequent states, if at all.

The second stage characterizes safety needs of security and safety; protection from the natural elements such as wind, rain and fire; and, security needs of order, law, limits, predictability and stability. 
The third stage is characterized by belongingness and love needs, family relationships, affection, and work, so that people will overcome feelings of loneliness, alienation, isolation from others, and rejection. Belongingness needs include both giving and receiving love, affection, and possessing a sense of belonging.

The fourth stage is characterized by esteem needs. According to Maslow, humans have a need for a stable, firmly based, high level of self-esteem, self-respect, and respect from others. When self-esteem needs are met a person feels self-confident, valued, and valuable as a person.

The last stage, the fifth stage is characterized by needs of selfactualization, which involves personal growth and fulfillment. A person's needed to be and do that which the person was born to do (such as becoming a doctor, a nurse, a teacher, etc.).

\section{Role of the Family in Providing for its Offspring:}

Although the definition and purpose of the family varies from culture to culture, and society-to-society, there is no single definition of what constitutes a "family" that is adequate for all purposes. However, globally, all families carry a primary responsibility of taking care of their offspring. Children are born into a family, with two parents, whether the parents are married, unmarried, and/or live apart. The family should be responsible for providing care and protection of their offspring, such as food, clothing, shelter, health care, education, economic stability, medical care, discipline and social control, understanding of right from wrong, and socialization into the culture. However, some families are so poor, destitute, and disorganized and malfunctioning, that they cannot minimally provide for their children. 1

Children are a potential human resource that, if not properly provided for, nurtured, and guided, will become a damaged product. They will not be able to contribute to the well being of society, and its continuity of and progress. Children represent the future generation, which should be preserved by the family and the society. To deny children the basic rights to access of food and nutrition, shelter, health care, education, and other rights, will destroy their lives. 
Egyptian Journal of Social Work (EJSW) http://ejsw.journals.ekb.eg

Print ISSN: 2356-9204 Online ISSN: 2356-9212 Vol 1, Issue 1, June 2015

\section{Role of the Family in Egypt in Caring for Children:}

Family and kinship in Egypt is said to be very important, and until recently, the family has remained the "most significant unit" in society, where kinship plays an important role in virtually all-social relations. The socialization of children emphasizes the integration among their kin group, and the important goal of marriage is to ensure the continuity of family (Retrieved November 16, 2008, from U. S. Library of Congress Country Studies,

http://www.lcweb2.loc.gov/cgi-

bin/query/r?frd/cstdy.@ field(DOCID=eg0073)

According to the State Information Service on Human Rights in Egypt (Article No. 9), "the family is seen as the basis of the society founded on religion, morality, and patriotism. The state is keen to preserve the genuine character of the Egyptian family ... and shall guarantee the protection of motherhood and childhood, take care of children and youth, and provide the suitable conditions for the development of their talents (Article 10)." (Retrieved November 22, 2008, from

http://www.sis.gov.eg/En/Politics/Hrights/04120000000000001.htm)

\section{Street Children at Egypt}

In Egypt, children under the age of 15 account for approximately 32 percent of the population, and adolescents represent a high percent of the population as well. Some estimates indicate that as many as 2 million children are living on the streets. A quarter of street children are believed to be less than 12 years old, two-thirds between the age of 13 and 16, while about 10 percent are 17-year-old (Leila, Al-Ahram Weekly. Retrieved November 22, 2008, from http://weekly.ahram.org.eg/rint/2007/847/eg11.htm.

According to Bibars (1998):

"Family abuse, domestic violence, and child sexual abuse and exploitation by a child's family are often the main reason why a large number of children run away from home and live on the streets (p. 202). The term "street children" tends to be associated with the notion of crime, vagrancy, and deviance. It was not until the 1990's was there an attempt made to differentiate between juvenile delinquents and the children 
Egyptian Journal of Social Work (EJSW) http://ejsw.journals.ekb.eg

Print ISSN: 2356-9204 Online ISSN: 2356-9212 Vol 1, Issue 1, June 2015

who live and/or work on the streets, or who are only there during the day The term "street children" carries a negative connotation and those who are street children get stigmatized (p. 202)."

Roberts (1991) defines the term "street children" in a variety of ways, depending on the set of circumstances that lead to the child becoming homeless, as follows:

- The term "street children" is loosely applied throughout the world to children who live and/or work on the streets.

- The term "street children" refers to homeless children who have little or no contact with their families and live on the streets. Many of these children survive by begging, theft, prostitution or some other marginal activity.

- The term "street children" also refers to a much larger group of children who live with their families but work on the streets. Many of these children are engaged in occupations such as street vending or petty services and many also attend school on a shift basis.

- The term "street child" may also be used to refer to an abandoned child who has to earn his or her upkeep from the streets by begging, shoe-shining, selling cigarettes, car washing, etc., as well as living on the streets (e.g., sleeping in bus stations, under bridges, or in old sewage pipes).

- The term may also be used to include the children of single or very poor parents whose children are the only sources of income for the family, providing livelihood by begging or even picking pockets on the streets.

Street life does not provide security and is very insecure and hazardous. Street children are exploited, persecuted, and in some countries may even be killed by death squads.

\section{Case Vignette of A Street Child in Egypt}

\section{"Devine" (Not her real name)}

Story recounted and quoted from UNICEF Egypt - Real Lives Still dreaming of a better future: A Cairo street girl recounts her traumatic experiences of living on the streets, by Lucy Ashton. Devine is 18 years old, and she has lived on the streets of Cairo for 4 


\section{Egyptian Journal of Social Work (EJSW) http://ejsw.journals.ekb.eg}

Print ISSN: 2356-9204 Online ISSN: 2356-9212 Vol 1, Issue 1, June 2015

years. (Retrieved November 16, 2008, from http://www.unicef.org/egypt/reallives_1317.html).

A month ago, Devine found a new place to sleep, a little public park off Qasr Al Aini Street --- a major thoroughfare in downtown Cairo. At night, Devine says the road is quiet, and in the park, she can sleep alone --- on one bothers her there. If she can find a scrap of cardboard to lie on, her night is more comfortable. "Street children can do anything in the world. They are prey to anything and they know things children should not," she says in a dry voice by way of introduction. I grew up in Aswan. My father fell in love with a drugs dealer, left my mother and went to Ismailla," --- a small town on the Suez Canal and several days travel from Aswan. "I needed him and went there alone to find him. My mother died and my father sent me back to Aswan to my uncles. They were very angry because I had traveled lone. They shaved off all my hair, beat me and burnt me as punishment. But I was never taken to the police station. The first time I went there was when my daughter died. There were some boys in a car, they held a knife to my neck, dragged me in and made me swallow pills. I fell asleep and when I woke I found myself in some wasteland. I don't remember what happened but a few weeks later my stomach hurt and a doctor told me I was pregnant."

About the same time her baby was born, Devine started to visit the Family Centre (name disguised) to receive support and food. One night a gang found them, and beat Devine savagely. Then they took her baby and suffocated it on the ground besides her. "I still don't understand why they would do that," she says recalling the horrific incident. Devine would like to return home to Aswan, but fears her uncles will kill her. She dreams of having a small room and a decent job, to begin her life. "But I am made to feel I am different in every way. The way people look at me makes me feel I am not human. That I am torn and they are neat."

\section{Neighborhood Factors to Protect Children from Child Abuse, Neglect, and Strengthen Families in Egypt:}

Despite the fact that Egypt is a signatory to the U.N. Declaration on the Rights of the Child, the Organization of African Unity (OAU), and the African Charter on the Rights and Welfare of 
the Child, and was an early signatory to the Convention on the Rights of the Child and one of six initiators of the first World Summit for Children, its children continue to suffer from abuse, neglect, homelessness, and exploitation. The recent passage of the new amendments to the Child Law of 1996 by the Egyptian Parliament to guarantee child basic rights and protections is said to give a "solid framework for the implementation of the rights of the child according to Moushira Khattab, Secretary General of the National Council for Childhood and Motherhood. These new amendments commit the "government to fulfilling the rights of children without discrimination on the basis of age, sex, geographic location, or religion." (The World Magazine, Egypt's Year of the Child. Retrieved 11/22/08, from http://www.theworldonline.ae?/p=848).

\section{Neighborhood Factors:}

Neighborhood factors that support child survival and development should be assessed and encouraged on all levels if children are to become healthy, successful, contributing adults to society. Neighborhood factors include adequate housing for individuals and families, access to nutritious meals, access to quality education, access to quality health care for children and adults, job training and employment opportunities for the un/der-employed, living wages, adequate transportation services, and social welfare services and benefits. Crime prevention tactics to reduce street and other crime is also important neighborhood conditions that need to be addressed if a society wishes to improve upon its conditions in urban centers particularly.

Creation of a national data base on children is essential, to include poverty indexes, parental status, age distribution of children, incidents of child abuse, child neglect, child abandonment, homeless and street children, those arrested for crimes, education of the children and adults, and child labor. In addition, there should be a repository of demographic data of the entire population, which should or could be housed in modern storage and retrieval systems for the safe keeping. This information is vital in providing a picture of the population, their needs, and solutions to consider. 


\section{Egyptian Journal of Social Work (EJSW) http://ejsw.journals.ekb.eg \\ Print ISSN: 2356-9204 Online ISSN: 2356-9212 Vol 1, Issue 1, June 2015}

The creation of a child abuse and neglect identification, reporting, storage, and response program should be develop, in order to have demographic data on this problem and the breadth and depth of the nature of and seriousness of child abuse and neglect. Services to this population need to be more extensive, if eradication of abuse and neglect is to be accomplished.

\section{Supporting and Strengthening Families:}

In summary, the family is the basic social unit of every society, and the natural environment for the growth, development, and wellbeing of all of its members, including the child. Children are society's most vulnerable, at risk population. Supports to help strengthen family life and productivity would go a long way in saving children, and preventing incidents of child abuse and neglect.

\section{References}

Arnold, E. (2002, June). The use of corporal punishment in child rearing in the West Indies. Science Direct, 6:2, pp. 141-145.

Bibars, I. (1998). Street children in Egypt: From the home to the street to inappropriate corrective institutions. Environment and Urbanization, 10:1, pp. 201- 216.

Commonwealth of Massachusetts, Massachusetts Department of Social Services (2002). Child Abuse Hurts Us All: Recognizing, Reporting, and Preventing Child Abuse and Neglect.

Crosson-Tower, C. 1992. In N. A. Cohen. Child Welfare: a Multicultural Focus. Boston, MA Allyn \& Bacon, 158-190.

DeCarolis, G., Southern, L. and Blake, F. (nd). Improving child welfare outcomes through systems of care: Building the Infrastructure: A guide for communities.U. S. Department of Health and Human Services, Administration for Children, Youth, and Families. Washington, DC.

Djeddah, C., Facchin, P., Ranzato, C., and Romer, C. (2000). Child abuse: Current problems and key public health challenges. Social Science and Medicine, 51(5): 905-915.

Dunne, M., et al. (2009). ISPCAN Child abuse screening tools retrospective version (ICAST-R): Delphi study and field-testing in seven countries. Child Abuse and Neglect, 33:11, pp. 815-825.

Egypt State Information Services. Constitution of the Arab Republic of Egypt, 2007. Retrieved November 22, 2008, from Http://www.sis.gov.eg/Constitution/. 


\section{Egyptian Journal of Social Work (EJSW) http://ejsw.journals.ekb.eg \\ Print ISSN: 2356-9204 Online ISSN: 2356-9212 Vol 1, Issue 1, June 2015}

Egypt State Information Services. Human Rights. Retrieved November 22, 2008, from

Http://www.sis.gov.eg/Politics/Hrights/.

Georgiades, S. D. (2009). Child abuse and neglect in Cyprus: An exploratory study of perceptions and experiences. Child Abuse Review, 18:60 - 71 .

Haj-Yahia, M. and Attar-Schwartz, S. (2008). Attitudes of Palestinian preschool teachers from Israel towards reporting of suspected cases of child abuse and neglect. Child and Family Social Work, 13:371 - 390.

Howard, K. S. and Brooks-Gunn, J. (2009). The role of home-visiting programs in preventing child abuse and neglect. Future of Children, 19(2): $119-146$.

International Society for Prevention of Child Abuse and Neglect. Protecting Children from the Storm. 2007 Annual Report. International Society for Prevention of Child Abuse and Neglect. XVIIth ISPCAN

International Congress on Child Abuse and Neglect: Towards a Caring and Non-Violent Community: A Child's Perspective. September 7 - 10, 2008.

Http://www.ispcan.org/congress2008/developing_country.html.

Retrieved 11/16/08.

Lehrmann, D. H. (2010). Advancing children's rights to be heard and protected: The model representation of children in abuse, neglect, and custody proceedings Act. Behavioral Science Law, 28:463 - 479.

Leila, R. Putting children first. Al-Ahram Weekly, Egypt. Retrieved November 11, 2008, from http://weekly.ahram.org.eg/print/2007/847/eg11.htm/.

Maslow, A. H. (1943). Theory of Human Motivation. Psychological Review, 50, pp. 370-396.

National Council for Childhood and Motherhood, Egypt. 2008 Amendments to the Child Law 12/1996.

Newman, D. and Barrow, C. (2008). Policy Forum: The reality of child abuse and neglect in Barbados --- towards a national child abuse reporting and management protocol. Journal of Eastern Caribbean Studies, 33(1): 85 100.

PaLa, B., Unalacak, M. and Unliioglu, I. (2011). Child maltreatment: Abuse and Neglect. 38(1): 121-127.

Roth, W. (2010). The Global Abuse of Children. In Roth, W. and Lawson, K. B., Globalization, Social Justice, and The Helping Professions. New York: State University of New York Press. 
Roberts, A. R. (1991). Notes from the field: Strategies for street children of Addis Ababa; defining issues of street children. Northeast Studies, Vol. 13, No. 2, p. 3 .

Quoted in Bibars, Iman (1998). Street children in Egypt: from the home to the street to inappropriate corrective institutions. Environment and Urbanization, Vol 10, No. 1, pp. $201-216$.

Schene, P. (2001, Spring). Meeting each family's needs: Using differential response in reports of child abuse and neglect. U. S. Department of Health and Human Services, National Child Welfare Resource Center for Family Centered Practice.

Sengupta, S. (2002, May 8). U. N. Prepares for a Debate on Dire Needs of Children. Retrieved 11/16/08, from Http://query.nytimes.com/gst/fullpage.html?res=9E02EEDA1530F93BA357 56C0A9649...

SPAAC (1993). Street children in Egypt. UNICEF, Cairo, Egypt. State Information Services. Egypt. Retrieved November 22, 2008, from http://www.sis.gov.eg/En/Politics/Hrights/04120000000000001.htm).

The World Magazine, Egypt's Year of the Child. Retrieved 11/22/08, from http://www.theworldonline.ae? / $\mathrm{p}=848$.

UNICEF. Plan of Action for Implementing the World Declaration on the Survival, Protection, and Development of Children in the 1990's. World Summit for Children 1990. Retrieved November 11, 2008, from Http://www.unicef.org/wsc/plan.htm.

UNICEF. The situation of children and women in Egypt. Retrieved 11/16/2008 from Http://www.unicef.org/egypt/overview.html.

UNICEF. The State of the World's Children 2008: Child Survival. Retrieved 11/22/08, from Http://www.unicef.org/sowc08/.

UNICEF. World Declaration on the Survival, Protection, and Development of Children. World Summit for Children 1990. Retrieved November 11, 2008, from Http://www.unicef.org/wsc/declare.htm.

United Nations. Convention on the Rights of the Child 1989.

U. S. Library of Congress Country Studies, Egypt. Retrieved November 16, 2008, from

http://www.lcweb2.loc.gov/cgi-

bin/query/r?frd/cstdy. @ field(DOCID=eg0073.

U. S. Department of Health and Human Services, (2007, June). Recognizing Child Abuse and Neglect: Signs and Symptoms. Administration for Children, Youth, and Families. Washington, DC. 
United States DHHS Bulletin. (August 2003). Children and Domestic Violence. Washington, DC: Child Welfare Information Gateway, Children's Bureau, and ACYF).

World Report on Violence and Health. Child abuse and neglect by parents and other caregivers.

Youssef, R.M., Kamel, M. I., Attia, M. S. (1998). Children experiencing violence: Parental use of corporal punishment. Child Abuse and Neglect. 22:10, pp. $959-973$.

Youssef, R. M. and Atta, H. Y. (1998). Child abuse and neglect: Its perception by those who work with children. Eastern Mediterranean Health Journal, 4:2, pp. 276-292. 